\title{
Relationship Marketing Strategy: An Operant Resource Perspective
}

\author{
Sreedhar Madhavaram \\ Cleveland State University, s.madhavaram@csuohio.edu \\ Elad Granot \\ Cleveland State University, e.granot@csuohio.edu \\ Vishag Badrinarayanan
}

Follow this and additional works at: https://engagedscholarship.csuohio.edu/bus_facpub

Part of the Marketing Commons

How does access to this work benefit you? Let us know!

Publisher's Statement

This article is (c) Emerald Group Publishing and permission has been granted for this version to appear here: http://www.emeraldinsight.com/doi/full/10.1108/JBIM-02-2013-0049. Emerald does not grant permission for this article to be further copied/distributed or hosted elsewhere without the express permission from Emerald Group Publishing Limited.

\section{Original Published Citation}

Madhavaram, S., Granot, E., Badrinarayanan, V. (2014). Relationship Marketing Strategy: An Operant Resource Perspective. Journal of Business \& Industrial Marketing, 29(4), pp. 275-283.

This Article is brought to you for free and open access by the Monte Ahuja College of Business at EngagedScholarship@CSU. It has been accepted for inclusion in Business Faculty Publications by an authorized administrator of EngagedScholarship@CSU. For more information, please contact library.es@csuohio.edu. 


\title{
Relationship marketing strategy: an operant resource perspective
}

\author{
Sreedhar Madhavaram and Elad Granot \\ Department of Marketing, Cleveland State University, Cleveland, Ohio, USA, and \\ Vishag Badrinarayanan \\ Department of Marketing, McCoy College of Business Administration, Texas State University, San Marcos, Texas, USA
}

\begin{abstract}
Purpose - The aim of this paper is to illustrate that the operant resource perspective of the service-dominant (S-D) logic can explicate how operant resources can influence relationship marketing (RM) strategy success.

Design/methodology/approach - After a brief discussion of the operant resource perspective of the service-dominant (S-D) logic, the paper reviews relationship marketing literature to identify and explore specific operant resources that can influence relationship marketing success.

Findings - This paper identifies several operant resources that have been empirically verified to have positive influence on relationship marketing success and several other operant resources that need further conceptual and empirical investigation.

Originality/value - The operant resource perspective of relationship marketing strategy and the operant resources identified in this paper provide the foundation for theory development and managerial practice.
\end{abstract}

Keywords Relationship marketing, Service dominant logic, Operant resources

Paper type Conceptual paper

\section{Introduction}

The fundamental imperative of relationship marketing strategy is that, to achieve competitive advantage and, thereby, superior financial performance, firms should identify, develop, and nurture a relationship portfolio (Madhavaram and Hunt, 2008). This view reflects the evolution of relationship marketing research. Specifically, since Berry (1983) first used the relationship marketing concept in the early $1980 \mathrm{~s}$, several researchers have examined the concept in different contexts. Consequently, as Hunt et al. (2006) note, over the last two and a half decades, the scope of the relationship marketing concept has broadened from a customer focus (e.g. Berry, 1983; Berry and Parasuraman, 1991) to a network focus (e.g. Gummesson, 1994; Gronroos, 1996). Reflecting this broadened focus, while Berry (1983, p. 25) defines relationship marketing as "attracting, maintaining, and - in multi-service organizations enhancing customer relationships," a decade later, Gummesson (1994, p. 2) proposes that "relationship marketing (RM) is marketing seen as relationships, networks, and interaction."

However, what kinds of relationships should be included under the network focus? As Hunt et al. (2006) note, understanding relationship marketing requires distinguishing between the discrete transaction, which has a "distinct beginning, short duration, and sharp ending by performance," and relational exchange, which "traces to previous agreements [and] ... is longer in duration, reflecting an ongoing process" (Dwyer et al., 1987, p. 13). Specifically, Morgan and Hunt (1994, p. 22) suggest, "relationship marketing refers to all marketing activities directed towards establishing, developing, and maintaining successful relational exchanges," whether or not the relational exchanges involve customers. This view parallels the rise of strategic network competition (Morgan and Hunt, 1994) and the conclusion of Aijo (1996, p. 15) that "there is a growing consensus on the definition of RM as involving the following aspects: a close long-term relationship between various (network) participants involved in exchanging something of value (total market process)."

Furthermore, Morgan and Hunt (1994) provide details of ten specific forms of relationship marketing:

1 the relational exchanges between manufacturers and their goods' suppliers; the relational exchanges involving service providers;

2 the strategic alliances between firms and their competitors;

3 the alliances between a firm and nonprofit organizations;

4 the relational exchanges between firms and local, state, or national governments;

5 the long-term exchanges between firms and ultimate customers; 
6 the relational exchanges of involving channels of distribution;

7 the relational exchanges involving functional departments;

8 the relational exchanges between a firm and its employees; and

9 the within-firm relational exchanges.

Noting that the rise of strategic network competition, as an alternative to traditional and hierarchical competition, has given a significant impetus to the rise of relationship marketing, Hunt et al. (2006) attempt to answer the question: why are some efforts at relationship marketing more successful than others? According to Hunt et al. (2006, p. 77) research in the area of relationship marketing has identified a minimum of eight types of factors that influence RM-based strategy success:

1 relational factors;

2 resource factors;

3 competence factors;

4 internal marketing factors;

5 information technology factors;

6 market offering factors;

7 historical factors; and

8 public policy factors.

The concept of resources and competences contributing to RM-based strategy success has its foundations in Hunt's (1997) work grounding relationship marketing in resourceadvantage (R-A) theory and parallels in the works of Vargo and Lusch (2004) and Palmatier et al. (2007). In fact, Palmatier et al. (2007), in trying to understand the drivers of successful interorganizational relationship performance, develop and test a post hoc framework that integrates the commitment-trust, dependence, transaction cost economics, and relational norms theoretical frameworks into a single model of interorganizational relationship performance and find that the model is consistent with a resource-based view (RBV) of relationship marketing. Correspondingly, in this paper, we approach relationship marketing strategy from the operant resources perspective proposed by Vargo and Lusch (2004) and explicated in greater detail by Madhavaram and Hunt (2008).

For Vargo and Lusch (2004), marketing's evolution toward a service-dominant (S-D) logic requires a focus on the intangible, dynamic resources that form the heart of competitive advantage and performance. That is, differentiating between operand resources (those on which an act or operation is performed) and operant resources (those that act on other resources), they elucidate that marketing should focus on specialized skills and knowledge as operant resources that provide competitive advantage. Furthermore, for S-D logic, a service-centered view is customer oriented and relational. Therefore, in this paper, we examine relationship marketing strategy from an operant resource perspective and focus on how operant resources can influence RM-based strategy success. The fundamental questions addressed here are: What kind of operant resources should firms focus on for a successful relationship marketing strategy? What are the implications of the operant resource perspective for relationship marketing theory? What are the implications of the operant resource perspective for relationship marketing practice?

In proposing answers for these questions, the remainder of this article is organized as follows. First, we present a brief overview of the operant resources perspective. Second, we identify and discuss specific operant resources with regard to relationship marketing strategy. Finally, we conclude with a discussion of implications of our paper for theory and practice.

\section{Operant resources}

This paper's focus on operant resources for RM-based strategy is framed on several questions: What is a resource? What are the kinds of operand and operant resources? How can previous research (e.g. on resources, competences, resource-advantage theory, capabilities, and dynamic capabilities) inform marketing's understanding of operant resources? In the context of RM-based strategy, what are the critical operant resources? Which specific research avenues need to be explored further?

As to what a resource is, resource-advantage theory defines resources as the "tangible and intangible entities available to the firm that enable it to produce efficiently and/or effectively a market offering that has value for some market segment(s)" (Hunt, 2000b, p. 138). As to exemplars of operand and operant resources, while operand resources are typically physical (e.g. raw materials), operant resources are typically human (e.g. the skills and knowledge of individual employees), organizational (e.g. controls, routines, cultures, and competences), informational (e.g. knowledge about market segments, competitors, and technology), and relational (e.g. relationships with competitors, suppliers, and customers) (Hunt, 2004). As to how previous research can inform marketing's understanding of operant resources, the initial conceptualization of operant resources by Constantin and Lusch (1994) provides a basis to consider concepts such as competences, capabilities, and dynamic capabilities as operant resources.

\section{Competences or capabilities}

The terms competences and capabilities are essentially interchangeable (Day, 1994; Madhavaram and Hunt, 2008). For example, Winter (2003, p. 991) defines an organizational capability as "a high-level routine (or collection of routines) that, together with its implementing input flows, confers upon an organization's management a set of decision options for producing significant outputs of a particular type," whereas Heene and Sanchez (1997) define a competence as an ability to sustain the coordinated deployment of assets (anything tangible or intangible the firm can use in its processes for creating, producing, and/or offering its products to a market) in a way that helps a firm achieve its goals. Therefore, because of the similar conceptualizations, competences and capabilities may be equated and defined as "socially complex, interconnected combinations of tangible basic resources (e.g. specific machinery, computer software and hardware) and intangible basic resources (e.g. specific organizational policies and procedures and the skills, knowledge, and experience of specific employees) that fit together coherently in a synergistic manner to enable firms to produce efficiently and/or effectively valued market offerings" (Hunt, 2000a, p. 188).

\section{Dynamic capabilities}

Teece et al. (1997, p. 516) define a dynamic capability as "the firm's ability to integrate, build, and reconfigure internal and 
external competencies to address rapidly changing environments." However, Zollo and Winter (2002, p. 340) observe that, while this conceptualization addresses the issue of what dynamic capabilities are for, "it ignores where dynamic capabilities come from." Therefore, they propose: "A dynamic capability is a learned and stable pattern of collective activity through which the organization systematically generates and modifies its operating routines in pursuit of improved effectiveness". For the purpose of this article, consistent with Madhavaram and Hunt (2008), we define any competence or capability as dynamic if, in rapidly changing environments, it enables the firm to modify itself so as to continue to produce, efficiently and/or effectively, market offerings for some market segment(s).

\section{RM-based strategy and operant resources}

Hunt et al. (2006, p. 77) synthesize the relationship marketing literature and note that "successful RM-based strategies have been linked to: improvements in competitive advantages in the marketplace (Barclay and Smith, 1997; Day, 2000; Hunt, 1997); superior financial performance (Boles et al., 2000; Hunt, 2000; Kalwani and Narayandas, 1995; Walter and Gemünden, 2000; Weber, 2000); increased levels of customer satisfaction (Abdul-Muhmin, 2002; Schellhase et al., 2000); organizational learning (Selnes and Sallis, 2003); partners' propensity to stay (Gruen et al., 2000; Jap, 2001; Verhoef, 2003); acquiescence by partners (Kumar et al., 1992; Morgan and Hunt, 1994); and decreases in uncertainty (Achrol and Stern, 1988; Morgan and Hunt, 1994)." These indicators of success, it should be noted, are not considered independent.

Furthermore, Hunt et al. (2006) explore why some firms' efforts are more successful than others when many firms adopt (or claim to adopt) RM-based strategies. In answering this question, among other factors, they propose that competence (operant resource) factors are important for RM-based strategy success. Relationship marketing theory concerning competence (operant resource) factors draws on the strategic management literature. Because competences are crucial for enabling firms to use their resources efficiently and/ or effectively, competences represent a logical extension of the resource-based view (Lado et al., 1992; Reed and DeFillippi, 1990). Indeed, R-A theory considers competences to be "higher order" resources (Hunt, 2000). Competences are often sources of competitive advantage because they are tacit, complex, and firm-specific (Reed and DeFillippi, 1990). As Nonaka (1994, p. 16) emphasizes, competences are "difficult to accurately describe and are deeply rooted in action, commitment, and involvement in a specific context." Therefore, because many competences cannot be explicitly articulated, they are "learned by doing" (Polanyi, 1966). Furthermore, because competences involve complex interrelationships among the skills of many individuals (Winter, 1987), they "are deeply embedded within the fabric of the organization" (Day, 1994, p. 38).

However, what specific operant resources can contribute to firms' relationship marketing strategies? How do they help firms? In answering these two questions, we explore prior research to identify relevant operant resources that can be critical to relationship marketing. Next, we discuss opportunities for investigating unexplored/new operant resources in the context of relationship marketing strategy.

\section{Operant resources investigated in research}

Research reveals network competence (Ritter and Gemunden, 2003, 2004), alliance competence (Lambe et al., 2002), internal market orientation (Gounaris, 2006), customer response capability (Jayachandran et al., 2004), interaction orientation (Ramani and Kumar, 2008), and relationship management capability (Jarratt, 2008) as potentially valuable operant resources for relationship marketing strategy. Of the six operant resources investigated in the extant literature:

1 network competence is nested in the context of interfirm partnerships;

2 alliance competence can be considered macro in the sense that alliances can involve competitors and non-profit organizations;

3 internal market orientation is in the context of firm and its employees; and

4 the remaining three operant resources, namely, customer response capability, interaction orientation, and relationship management capability involve relationships with customers in business-to-business as well as business-to-consumer contexts.

Network competence. For Ritter and Gemunden (2003, 2004), network competence enables a firm to establish and use relationships with other firms. They conceptualize network competence as having two facets: network management task execution and network management qualifications. Investigating 308 German firms, they establish a positive relationship between network competence and the innovation success of firms. Also, they note that firms with a high level of network competence follow more realistic and more marketoriented innovation development paths and establish a better relationship marketing strategy for selling innovative products.

Alliance competence. In the context of interfirm relationships, researchers suggest that RM-based strategy success is influenced significantly by a firm's ability to develop an alliance competence, which is defined as "an organizational ability for finding, developing, and managing alliances" (Lambe et al., 2002, p. 145). To improve RM-based strategy success, firms must identify and integrate resources that promote the identification, development, and management of alliances. Knowledge management is a key component of alliance competence development and maintenance. As Kale et al. (2002) maintain, firms must be able to collect and disseminate alliance "know-how," which often consists of tacit knowledge that is based considerably on a firm's alliance history. A significant portion of this knowledge resides within the individuals involved in relationship management. Firms that can find ways to facilitate the dissemination of individual-based knowledge (both within and between partners) will be more successful at forming and maintaining interfirm relationships. For example, Simonin (1997) finds that, when alliance managers learn how to collaborate with alliance partners (i.e. share knowledge), alliances are more successful. Therefore, the development of an alliance competence requires knowledge accessibility, facilitative mechanisms, and effective knowledge leveraging (Inkpen, 1998; Spekman et al., 2000). Through empirical investigation, Lambe et al. (2002) show that alliance competence is a key antecedent to alliance success.

Internal market orientation. Synthesizing the voluminous internal marketing (IM) literature, Gounaris (2006) suggests 
that IM refers to the strategies and programs that the firm implements in its internal market (employees at all levels) in order to attain its external market objectives. Drawing from research on market orientation (e.g. Kohli and Jaworski, 1990) and internal relationships (e.g. Gummesson, 1994), Gounaris (2006) conceptualizes internal market orientation has having three dimensions: internal intelligence generation, internal intelligence dissemination, and response to internal intelligence generation. Furthermore, he conceptualizes: identification of exchange value and awareness of labor market conditions as two facets of internal intelligence generation; communication between managers and employees and communication among managers as two facets of internal intelligence dissemination; and internal segmentation, job description, remuneration system, management concern, training, and internal targeting as six facets of response to intelligence. Analyzing data from 583 interviews, he finds a positive influence of internal market orientation on empowerment, job satisfaction, and participation in decision-making of firms' employees.

Customer response capability. How firms respond to customers is critical to the firms in the context of customeroriented relationship marketing strategies. For Jayachandran et al. (2004), a firm's competence in satisfying customer needs through effective and quick responses is critical to its success. Therefore, they conceptualize customer response capability in terms of customer response expertise and customer response speed. While customer response expertise refers to the extent to which the responses of an organization effectively meet customer needs, customer response speed refers to the extent to which the organization's responses to customer needs are rapid. Reporting results from a study involving 227 organizations, they conclude that customer response capability is related positively to performance.

Interaction orientation. As advances in technology have resulted in increased opportunities for interactions between firms and customers, customer expectations for customized market offerings have gone up (Ramani and Kumar, 2008). Consequently, interaction orientation can result in competitive advantages for firms. For Ramani and Kumar (2008, p. 27), “an interaction orientation reflects in firm's ability to interact with its individual customers and to take advantage of information obtained from successive interactions to achieve profitable customer relationships." Through exploratory interviews with 48 managers from 26 business-to-business and 18 business-to-consumer firms, Ramani and Kumar (2008) conceptualize interaction orientation as a composite construct that captures a firm's belief in the customer concept, a firm's interaction response capacity that reflects its ability to use dynamic database systems and processes, a firm's customer empowerment practices that help shape customer- firm interactions and customer-customer interactions, and a firm's customer value management practices that guide its marketing resource allocation decisions. Furthermore, Ramani and Kumar (2008) find interaction orientation to have positive influences for both business-to-business and business-toconsumer firms.

Relationship management capability. Integrating literature streams on dynamic capabilities, the resource-advantage theory of competition, and capability research in innovation and information technology management, Jarratt (2008) argues that the second-order constructs of relationship infrastructure, relationship learning, and relationship behavior represent a relationship management capability (RMC). Furthermore, surveying senior executives responsible for customer relationship management in manufacturing and business service firms in the UK, Jarratt (2008) suggests that relationship management systems, implemented through collaborative and flexible behaviors, and renewed through adaptive and generative knowledge derived from experience and challenging current relationship management assumptions, are key dimensions of a RMC. The findings are consistent with Madhavaram and Hunt's (2008) contention that some operant resources have interconnected, basic operant resources as building blocks.

\section{Unexplored/new operant resources and RM Strategy}

Next, we turn our attention to operant resources that have been conceptualized but not empirically tested or operant resources whose conceptualization is relevant to $\mathrm{RM}$ strategies. Specifically, while market relating capability and knowledge management capability are operant resources that have been previously conceptualized that have not been empirically tested, we conceptualize relationship portfolio management capability, interorganizational information systems capability, customer lifetime value (CLV) management capability, and co-creation competence as operant resources that are important for further exploration.

Market relating capability. Day (2000) maintains that firms can develop a market-relating (customer-relating) capability (or competence). For him, a market-relating capability results from firms developing concomitantly three organizational components (Day, 2000, p. 77):

1 an organizational orientation that makes customer retention a priority and gives employees, as an overall willingness to treat customers differently, wide latitude to satisfy them;

2 a configuration that includes the structure of the organization, its processes for personalizing product or service offerings, and its incentives for building relationships; and

3 information about customers that is in-depth, relevant, and available through IT systems in all parts of the company.

That is, orientation, knowledge and skills, and integration and alignment of processes are the three elements of a marketrelating capability. These three elements interact and reinforce each other. As Day (2000, p. 24) acknowledges, "Not every firm can or should try to master the marketrelating capability." However, because market-relating capabilities are difficult to imitate, they often result in sustainable competitive advantages over rivals.

Knowledge management competence. For Arnett and Badrinarayanan (2005), a firm's knowledge management competence has three components: knowledge development, knowledge dissemination, and knowledge application. They propose that knowledge management is an important resource for firms implementing customer-needs driven CRM (customer relationship management) strategies. However, as can be seen from the conceptualization, the application of knowledge management competence can benefit and be expanded to all other forms of relationships.

Relationship portfolio management capability. Not all relationships should be nurtured. As Gummesson (1994, 
p. 17) emphasizes, "Not all relationships are important to all companies all of the time...some marketing is best handled as transaction marketing." That is, not all of the possible relationships with potential stakeholders are advantageous. Therefore, it is important that managers develop an ability to manage effectively their "relationship portfolios." Hunt (1997) suggests that firms should develop a relationship portfolio that is comprised of relationships that add to firm efficiency and/or effectiveness. He maintains that "every potential and existing relationship should be scrutinized to ensure that it contributes to the firm's ability to efficiently and/or effectively produce a market offering that has value to some market segment(s)" (Hunt, 1997, p. 439). Therefore, the operant resource explanation of RM-based strategy success urges marketers to manage well their relationship portfolios.

Interorganizational information systems capability. Given that competition has evolved to involve strategic networks, for relationship marketing theory, collaborative among network participants relationships require considerable transfers of technology and knowledge sharing among partners (Lam, 1997). Consequently, successful RM-based strategies often require firms to adopt interorganizational information systems and create organizational processes that are conducive to knowledge use and sharing among all network participants. For example, as Hunt et al. (2006) note, to specifically foster supplier-manufacturer relationships, the US automobile manufacturers developed an Extranet called the Automotive eXchange Network (AXN), which links automobile manufacturers with several thousand suppliers (Evans and Wurster, 1997). Also, as the adoption of interorganizational information systems opens the doors for exchange and use of, sometimes, sensitive knowledge, requires the existence of a close relationship among the firms involved, "Interorganizational systems involve the cooperation and commitment of all participating members" (Premkumar and Ramamurthy, 1995). Furthermore, for Hunt et al. (2006, p. 80), the adoption of interorganizational information systems could result in increases in both internal and interorganizational efficiency (Bakos and Treacy, 1986; Johnston and Vitale, 1988), improvements in relationships among partners (Vijayasarathy and Robey, 1997), and increases in interfirm cooperation (Vijayasarathy and Robey, 1997).

Following Hunt et al. (2006), we conceptualize interorganizational information systems capability (IISC) as having four components:

1 focal firm's ability to develop and maintain cooperative cultures with relevant network participants;

2 focal firm's ability to develop appropriate interorganizational information systems for relevant network participants;

3 focal firm's ability to control the extent of knowledge exchange and use; and

4 ability to develop integrated information and communication infrastructures.

Firms must realize that the development of interorganizational information systems and ensuring cooperation among network participants are two different issues. Often, developing cooperative cultures is more difficult than developing systems and firms must be adept at both to realize success in the context of strategic network competition.

Next, the focal firm should develop appropriate systems for appropriate partners in the network as requirements in terms of scope and depth of knowledge use could vary very widely. Furthermore, extent of knowledge sharing can also vary widely for network participants. Accordingly, the focal firm should develop the ability to control the extent of knowledge sharing with different partners in the strategic network. Finally, to improve the success of interorganizational information systems, firms must also adapt their existing infrastructures in ways that facilitate the collaboration and sharing of knowledge across internal organizational boundaries (Gold et al., 2001). A firm's infrastructure must link its information systems with its communication systems. As Menon and Varadarajan (1992), p. 53; italics added) emphasize, "relevant information must be produced and disseminated to the various departments and managers in the most appropriate form to enhance use." Therefore, information technology (IT) infrastructure facilitates knowledge use and knowledge sharing through better internal communication flows. Therefore, the information infrastructures and the communication infrastructures within firms must be integrated.

Customer lifetime value (CLV) management capability. In recent years, the concept of management of customer retention (Reichheld et al., 2000) has contributed to the emergence of customer lifetime value (CLV) concept (Reinartz and Kumar, 2002). According to Kumar (2006), there are eight specific CLV-based strategies: selecting the best customers, making loyal customers profitable, optimally allocating resources, pitching right products to the rights customers at the right time, linking acquisition and retentions resources to profitability, preventing customer attrition, encouraging multi-channel shopping behavior, and maximizing brand value. In fact, Kumar et al. (2008) apply CLV-based strategies to 35,000 customers of IBM and find that, the CLV-based strategies led to reallocation of resources for about 14 percent of the customers as compared to the allocation rules used previously (which were based on past spending history) and the CLV-based resource reallocation led to an increase in revenue of about $\$ 20$ million (a tenfold increase) without any changes in the level of marketing investment.

Therefore, in the context of CLV, managing relationships with customers is especially challenging for many firms because they engage in many different types of transactions, and their customers' needs and wants vary considerably. Accordingly, customer relationship management can be critical to CLV. To meet these challenges, many firms are turning to formal, customer relationship management (CRM) programs that center on segmenting customers based on needs and/or profitability and designing and implementing programs to allocate efficiently/effectively the appropriate resources to each customer (Srivastava et al., 1999). Appropriate resource allocation enables benefits to flow to both the organization and its customers (Ramsey, 2003). Following Kumar's (2006) eight CLV-based strategies, CRM programs that support CLV can involve a relationship management component (e.g. support teams and loyalty programs) and a data-driven component (e.g. identifying profitable segments through statistical techniques) (Dowling, 2002). The first component of is stressed by the Industrial 
Marketing and Purchasing (IMP) Group (Axelsson and Easton, 1992; Ford, 1990; Hakansson, 1982). In this approach, informational technology supports CLV-based strategies such as making loyal customers profitable, pitching right products to the rights customers at the right time, preventing customer attrition, encouraging multichannel shopping behavior, and maximizing brand value. In contrast, the second component of is driven by information technology. That is, customer data are analyzed to uncover previously unknown relationships that can be used to develop marketing strategies. Here, the second component supports CLV-based strategies like selecting the best customers, optimally allocating resources, and linking acquisition and retentions resources to profitability.

In support of the second component, data-driven programs emphasize databases and the use of data-mining techniques such as decision trees, neural networks, and cluster analysis (Nairn and Bottomley, 2003). "Data-mining attempts to formulate, analyze, and implement basic induction processes that facilitate the extraction of meaningful information and knowledge from unstructured data" (Grossman et al., 1999, p. 1). Such approaches are based on the premise that the sheer amount and complexity of information-rich data collected and stored within firms prevents managers from seeing all of the useful relationships within their databases. The results of data-mining efforts may be insights, rules, or predictive models that can be used to better manage CLV. For example, as Hunt et al. (2006) note, data-mining can be used to: predict customer responses to direct marketing efforts; identify important customers who warrant special attention; and isolate customers who cost more than they contribute and, therefore, should be abandoned (Peacock, 1998a, b).

Co-creation competence. For S-D logic (Vargo and Lusch, 2004), two key foundational premises are the customer is always a co-creator and service-orientation is customer oriented and relational. In fact, in a recent article, Payne et al. (2009) address the issue of co-creating brands and explore the design and management of the brand relationship experience for an innovative, new product. This concept of co-creation can be a fertile, new research avenue. For example, what makes one firm better others in co-creating market offerings? What constitutes co-creation competence, i.e. what are the elemental resources that make up co-creation competence, an operant resource? Also, is co-creation with competitors, non-profit organization, and local, state, and federal governments different from co-creation with customers? If so, what different operant resources are required for co-creation with different entities that firms can have partnerships with?

\section{Discussion}

As marketing is evolving toward a dynamic, evolutionary process, service-centered view, marketers should focus on specialized skills and knowledge as operant resources that provide competitive advantage. Therefore, reflecting this evolution, research in relationship marketing strategy should also focus on operant resources. To some extent, as identified in this paper in terms of research on operant resources, there is evidence that R-M based strategy research is moving in the right direction through its increased focus on competences, capabilities, and dynamic capabilities. Accordingly, in this paper, we identified network competence, alliance competence, internal market orientation, customer response capability, interaction orientation, and relationship management capability as operant resources that have been empirically verified to have positive influences on firms. Next, we identified market relating capability and knowledge management competence as operant resources that have been proposed in the literature but have not been empirically tested. Furthermore, based on prior literature, we propose relationship portfolio management capability, interorganizational information systems capability, customer lifetime value (CLV) management capability, and co-creation competence as operant resources that can be critical to the success of RM based strategies.

Our paper has implications for theory and practice. From a theoretical perspective, we integrate and expand current understanding on appropriate operant resources that contribute to the RM-based strategy success. Although Vargo and Lusch (2004) call for marketing theoreticians to focus more extensively on operant resources, scholarly work in this area has not progressed adequately and, specifically, very little research attention has been afforded to the types of operant resources that contribute to RM-based strategy success. The current work, therefore, extends research by identifying both established and newer capabilities and competences which could be considered as operant resources that lead to RM-based strategy success and competitive advantage. Despite the conceptual nature of this work, the operant resources identified and presented here are theoretically grounded in robust literature streams with some of them possessing empirical support regarding their implications for RM-based strategy success. As a result, while the concepts presented here can serve as impetus for future inquiry by researchers, they also represent ideas for managers to improve RM-based strategy success. For example, we identified Day's (1994) market relating capability as an operant resource that involves creating and maintaining relationships with their most valuable customers through a relationship orientation that pervades the mindset, values, and norms of the organization, a deep knowledge of the customers that is put to work throughout the organization, and the key processes that are internally integrated and externally aligned with the corresponding processes of the firm's customers. Research into the measurement, antecedents, and consequences of market relating capability can be useful for relationship marketing strategy. Similarly, the conceptualization, measurement, antecedents, and consequences of relationship portfolio management capability can prove fruitful for relationship marketing strategy. With reference to business, according to the service-centered dominant logic, operant resources are the source of economic growth. Therefore, advantages in operant resources will give firms competitive advantages in the marketplace.

Consequently, firms should consciously and continuously aim to acquire and develop operant resources for RM based strategies that can provide them with competitive advantages and develop organizational policies, learning systems, and cultures that will facilitate the acquisition and development of operant resources. Indeed, firms' managers can view firms as bundles of operant resources that can guide relationship marketing strategy recognition, understanding, creation, selection, implementation, and modification. In addition, firms should also consciously and continuously strive for 
mastery in their operant resources. In addition, several of the operant resources identified in this paper are limited in their applicability to specific kinds of relationships. For example, internal market orientation is in the context of firm and its employees, and customer response capability, interaction orientation, and relationship management capability involve relationships with customers. Therefore, there is a lot scope for investigating operant resources in the contexts all forms relationships. For example, the role of operant resources in the context of firms and non-profit organizations could provide interesting avenues for research.

In conclusion, the operant resources identified, presented, and discussed in this article extend and elaborate on the operant resources concept in the relationship marketing literature. We hope that this article acts as a catalyst for further exploration of operant resources in the contexts of $\mathrm{R}-\mathrm{M}$ based strategy.

\section{References}

Abdul-Muhmin, A.G. (2002), "Effects of suppliers marketing program variables on industrial buyers relationship satisfaction and commitment", The fournal of Business E Industrial Marketing, Vol. 17 No. 7, pp. 637-651.

Achrol, R.S. and Stern, L.W. (1988), "Environmental determinants of decision making uncertainty in marketing channels", fournal of Marketing Research, Vol. 25 No. 1, pp. 36-50.

Aijo, T.S. (1996), “The theoretical and philosophical underpinnings of relationship marketing: environmental factors behind the changing marketing paradigm", European Fournal of Marketing, Vol. 30 No. 2, pp. 8-18.

Arnett, D.B. and Badrinarayanan, V. (2005), "Enhancing customer-needs driven CRM strategies: core selling teams, knowledge management competence, and relationship marketing competence”, fournal of Personal Selling \& Sales Management, Vol. 25 No. 4, pp. 329-343.

Axelsson, B. and Easton, G. (1992), Industrial Networks: A New View of Reality, Gower, London.

Bakos, J.Y. and Treacy, M.E. (1986), "Information technology and corporate strategy: a research perspective", MIS Quarterly, Vol. 10 No. 2, pp. 107-119.

Barclay, D.W. and Smith, J.B. (1997), "The effects of organizational differences and trust on the effectiveness of selling partner relationships", fournal of Marketing, Vol. 61 No. 1, pp. 3-20.

Berry, L.L. (1983), "Relationship marketing”, in Berry, L.L., Shostock, G.L. and Upah, G.D. (Eds), Emerging Perspectives on Services Marketing, American Marketing Association, Chicago, IL, pp. 25-28.

Berry, L.L. and Parasuraman, A. (1991), Marketing Services, The Free Press, New York, NY.

Boles, J., Brashear, T., Bellenger, D. and Barksdale, J.H. (2000), "Relationship selling behaviors: antecedents and relationship with performance", The fournal of Business $\mathcal{E}$ Industrial Marketing, Vol. 15 Nos 2/3, pp. 141-153.

Constantin, J.A. and Lusch, R.F. (1994), Understanding Resource Management, The Planning Forum, Oxford, OH.

Day, G.S. (1994), "The capabilities of market-driven organizations", fournal of Marketing, Vol. 58 No. 4, pp. 37-52.
Day, G.S. (2000), "Managing marketing relationships", Fournal of the Academy of Marketing Science, Vol. 28 No. 1, pp. 24-30.

Dowling, G. (2002), “Customer relationship management: in B2C markets, often less is more", California Management Review, Vol. 44 No. 3, pp. 87-104.

Dwyer, F.R., Schurr, P.H. and Oh, S. (1987), "Developing buyer-seller relationships", fournal of Marketing, Vol. 51 No. 2, pp. 11-27.

Evans, P.B. and Wurster, T.S. (1997), "Strategy and the new economics of information", Harvard Business Review, Vol. 75 No. 5, pp. 71-82.

Ford, D. (1990), Understanding Business Markets: Interaction, Relationships, and Networks, Academic Press, London.

Gold, A.H., Malhotra, A. and Segars, A.H. (2001), "Knowledge management: an organizational capabilities perspective", Fournal of Management Information Systems, Vol. 18 No. 1, pp. 185-214.

Gounaris, S.P. (2006), "Internal-market orientation and its measurement", Fournal of Business Research, Vol. 59, pp. 432-448.

Gronroos, C. (1996), "Relationship marketing: strategic and tactical implications", Management Decision, Vol. 34 No. 3, pp. 114-135.

Grossman, R., Kasif, S., Moore, R., Rocke, D. and Ullman, J. (1999), "Data mining research: opportunities and challenges: a report of three NSF workshops on mining large, massive, and distributed data", supported in part by NSF Grant IRI-9802160.

Gruen, T.W., Summers, J.W. and Acito, F. (2000), "Relationship marketing activities, commitment, and membership behaviors in professional associations", Fournal of Marketing, Vol. 64 No. 3, pp. 34-49.

Gummesson, E. (1994), "Making relationship marketing operational", International fournal of Service Industry Management, Vol. 5 No. 5, pp. 5-20.

Hakansson, H. (ed) (1982), International Marketing and Purchasing of Industrial Groups: An Interaction Approach, John Wiley \& Sons, Chichester.

Heene, A. and Sanchez, R. (1997), Competence-Based Strategic Management, Wiley, New York, NY.

Hunt, S.D. (1997), "Competing through relationships: grounding relationship marketing in resource-advantage theory", Fournal of Marketing Management, Vol. 13 No. 5, pp. 431-445.

Hunt, S.D. (2000), A General Theory of Competition, Sage Publications, Thousand Oaks, CA.

Hunt, S.D. (2004), "On the service-centered dominant logic of marketing”, fournal of Marketing, Vol. 68 No. 1, pp. 21-22.

Hunt, S.D., Arnett, D.B. and Madhavaram, S. (2006), "Explanatory foundations of relationship marketing theory", Fournal of Business and Industrial Marketing, Vol. 21 No. 2, pp. 72-87.

Inkpen, A.C. (1998), "Learning and knowledge acquisition through international strategic alliances", Academy of Management Executive, Vol. 12 No. 4, pp. 69-80.

Jap, S.D. (2001), "The strategic role of the salesforce in developing customer satisfaction across the relationship lifecycle", fournal of Personal Selling $\mathcal{E}$ Sales Management, Vol. 21 No. 2, pp. 95-109. 
Jarratt, D. (2008), “Testing a theoretically constructed relationship management capability", European fournal of Marketing, Vol. 42 Nos 9/10, pp. 1106-1132.

Jayachandran, S., Hewett, K. and Kaufman, P. (2004), "Customer response capability in a sense-and-response era: the role of customer knowledge process", fournal of the Academy of Marketing Science, Vol. 32 No. 3, pp. 219-233.

Johnston, H.R. and Vitale, M.R. (1988), "Creating competitive advantage with interorganizational information systems", MIS Quarterly, Vol. 12 No. 2, pp. 153-165.

Kale, P., Dyer, J.H. and Singh, H. (2002), "Alliance capability, stock market response, and long-term alliance success: the role of the alliance function", Strategic Management fournal, Vol. 23 No. 8, pp. 747-767.

Kalwani, U.M. and Narayandas, N. (1995), "Long-term manufacturing-supplier relationships: do they pay off for supplier firms?", fournal of Marketing, Vol. 51 No. 1, pp. 1-16.

Kohli, A.K. and Jaworski, B. (1990), "Market orientation: the construct, research propositions, and managerial implications", fournal of Marketing, Vol. 54, pp. 1-18.

Kumar, N., Stern, L.W. and Achrol, R.S. (1992), "Assessing retailer performance from the perspective of the supplier", Fournal of Marketing Research, Vol. 29 No. 2, pp. 238-253.

Kumar, V. (2006), "Customer lifetime value: a databased approach", fournal of Relationship Marketing, Vol. 5 Nos 2/3, pp. 7-35.

Kumar, V., Venkatesan, R., Bohling, T. and Beckmann, D. (2008), "The power of CLV: managing customer lifetime value at IBM", Marketing Science, Vol. 27 No. 4, pp. 585-599.

Lado, A.A., Boyd, N.G. and Wright, P. (1992), "A competency-based model of sustainable competitive advantage", fournal of Management, Vol. 18 No. 1, pp. 77-91.

Lam, A. (1997), "Embedded firms, embedded knowledge: problems of collaboration and knowledge transfer in global cooperative ventures", Organizational Studies, Vol. 18 No. 6, pp. 973-996.

Lambe, C.J., Spekman, R.E. and Hunt, S.D. (2002), "Alliance competence, resources, and alliance success: conceptualization, measurement, and initial test", Fournal of the Academy of Marketing Science, Vol. 30 No. 2, pp. 141-158.

Madhavaram, S. and Hunt, S.D. (2008), "The service dominant logic and a hierarchy of operant resources: developing masterful operant resources and implications for marketing strategy", fournal of the Academy of Marketing Science, Vol. 36 No. 1, pp. 67-82.

Menon, A. and Varadarajan, P.R. (1992), "A model of marketing knowledge use within firms", fournal of Marketing, Vol. 56, pp. 53-71.

Morgan, R.M. and Hunt, S.D. (1994), "The commitmenttrust theory of relationship marketing", fournal of Marketing, Vol. 58 No. 3, pp. 20-38.

Nairn, A. and Bottomley, P. (2003), "Something approaching science? Cluster analysis procedures in the CRM era", International fournal of Market Research, Vol. 45 No. 2, pp. 241-260.

Nonaka, I. (1994), "A dynamic theory of organizational knowledge creation", Organization Science, Vol. 5 No. 1, pp. 14-37.
Palmatier, R.W., Dant, R.P. and Grewal, D. (2007), "A comparative longitudinal analyses of theoretical perspectives of interorganizational relationship performance", fournal of Marketing, Vol. 71, pp. 172-194.

Payne, A., Storbacka, K., Frow, P. and Knox, S. (2009), "Co-creating brands: diagnosing and designing the relationship experience", Fournal of Business Research, Vol. 62, pp. 379-389.

Peacock, P.R. (1998a), "Data mining in marketing: part 1", Marketing Management, Vol. 6 No. 4, pp. 8-18.

Peacock, P.R. (1998b), "Data mining in marketing: part 2", Marketing Management, Vol. 7 No. 1, pp. 15-25.

Polanyi, M. (1966), The Tacit Dimension, Doubleday, Garden City, NY.

Premkumar, G. and Ramamurthy, K. (1995), "The role of interorganizational and organizational factors on the decision mode for adoption of interorganizational systems", Decision Sciences, Vol. 26 No. 3, pp. 303-336.

Ramani, G. and Kumar, V. (2008), "Interaction orientation and firm performance", fournal of Marketing, Vol. 72, pp. 27-45.

Ramsey, S.S. (2003), "Introduction: strategy first, then CRM", in Freeland, J.G. (Ed.), The Ultimate CRM Handbook, McGraw-Hill, New York, NY, pp. 13-17.

Reed, R. and DeFillippi, R.J. (1990), "Causal ambiguity, barriers to imitation, and sustainable competitive advantage", Academy of Management Review, Vol. 15 No. 1, pp. 88-117.

Reichheld, F.F., Markey, R.G. Jr and Hopton, C. (2000), "The loyalty effect - the relationship between loyalty and profits”, European Business fournal, Vol. 12, pp. 134-139.

Reinartz, W.J. and Kumar, V. (2002), "The mismanagement of customer loyalty", Harvard Business Review, Vol. 80 No. 7, pp. 86-94.

Ritter, T. and Gemunden, H.G. (2003), "Network competence: its impact on innovation success and its antecedents", fournal of Business Research, Vol. 56, pp. 745-755.

Ritter, T. and Gemunden, H.G. (2004), "The impact of a company's business strategy on its technological competence, network competence and innovation success", Fournal of Business Research, Vol. 57, pp. 548-556.

Schellhase, R., Hardock, P. and Ohlwein, M. (2000), "Customer satisfaction in business-to-business marketing: the case of retail organizations and their suppliers", The fournal of Business $\mathcal{E}$ Industrial Marketing, Vol. 15 Nos 2/3, pp. 106-121.

Selnes, F. and Sallis, J. (2003), "Promoting relationship learning”, Fournal of Marketing, Vol. 67 No. 3, pp. 96-107.

Simonin, B.L. (1997), "The importance of collaborative know-how: an empirical test of the learning organization", Academy of Management fournal, Vol. 40 No. 5, pp. 1150-1174.

Spekman, R.E., Isabella, L.A. and MacAvoy, T.C. (2000), Alliance Competence: Maximizing the Value of Your Partnerships, John Wiley \& Sons, New York, NY.

Srivastava, R.K., Shervanie, T.A. and Fahey, L. (1999), "Marketing, business processes, and shareholder value: an organizationally embedded view of marketing activities and the discipline of marketing", fournal of Marketing, Vol. 63, Special Issue, pp. 168-179.

Teece, D. and Pisano, G. (1997), "Dynamic capabilities and strategic management", Strategic Management fournal, Vol. 18 No. 7, pp. 509-533. 
Vargo, S.L. and Lusch, R.F. (2004), "Evolving to a new dominant logic for marketing", fournal of Marketing, Vol. 68 No. 1, pp. 1-17.

Verhoef, P.C. (2003), "Understanding the effect of customer relationship management efforts on customer retention and customer share development", fournal of Marketing, Vol. 67 No. 4 , pp. $30-45$.

Vijayasarathy, L.R. and Robey, D. (1997), "The effect of EDI on market channel relationships in retailing", Information E Management, Vol. 33 No. 2, pp. 73-86.

Walter, A. and Gemünden, H.G. (2000), "Bridging the gap between suppliers and customers through relationship promoters: theoretical considerations and empirical results", The fournal of Business E Industrial Marketing, Vol. 15 Nos 2/3, pp. 86-105.

Weber, J.A. (2000), "Partnering with distributors to stimulate sales: a case study", The fournal of Business $\mathcal{E}$ Industrial Marketing, Vol. 15 Nos 2/3, pp. 154-162.
Winter, S.G. (1987), "Knowledge and competence as strategic assets", in Teece, J (Ed.), The Competitive Challenge, Ballinger, Cambridge, MA, pp. 159-184.

Winter, S.G. (2003), "Understanding dynamic capabilities", Strategic Management fournal, Vol. 24, pp. 991-995.

Zollo, M. and Winter, S.G. (2002), "Deliberate learning and the evolution of dynamic capabilities", Organizational Science, Vol. 13 No. 3, pp. 339-351.

\section{Corresponding author}

Sreedhar Madhavaram can be contacted at: s.madhavaram@ csuohio.edu 